\title{
REVIEW
}

\section{Gephyrin: a central GABAergic synapse organizer}

\author{
Gayoung Choii ${ }^{1}$ and Jaewon Ko ${ }^{1,2}$
}

Gephyrin is a central element that anchors, clusters and stabilizes glycine and $\boldsymbol{\gamma}$-aminobutyric acid type A receptors at inhibitory synapses of the mammalian brain. It self-assembles into a hexagonal lattice and interacts with various inhibitory synaptic proteins. Intriguingly, the clustering of gephyrin, which is regulated by multiple posttranslational modifications, is critical for inhibitory synapse formation and function. In this review, we summarize the basic properties of gephyrin and describe recent findings regarding its roles in inhibitory synapse formation, function and plasticity. We will also discuss the implications for the pathophysiology of brain disorders and raise the remaining open questions in this field.

Experimental \& Molecular Medicine (2015) 47, e158; doi:10.1038/emm.2015.5; published online 17 April 2015

\section{INTRODUCTION}

Synapses, which are the fundamental information-processing units of neural circuits, form the basis for all brain functions by controlling the excitation-to-inhibition balance. Synapses form via a coordinated process that orchestrates (sequentially or in parallel) a variety of dynamically regulated cellular events. Various molecular and cellular mechanisms underlying synapse formation have been elucidated. For example, multiple synaptic adhesion molecules have been shown to initiate physical contact between axons and dendrites, recruit other synaptic molecules (e.g., scaffolding proteins) to assemble nascent synaptic sites and specify their properties to organize functional synapses (reviewed in refs 1-3). Numerous studies have examined the development of excitatory synapse, and the identification of inhibitory synapse components has accelerated in recent years. This has allowed researchers to establish a conceptual framework for the organization of inhibitory synapse development.

Postsynaptic scaffolding molecules are key components in the organization of functional synapses. They ensure the accurate accumulation of neurotransmitter receptors in precise apposition to presynaptic release sites, as this is required for reliable synaptic transmission. Scaffolding molecules also interact with cytoskeletal anchoring elements to provide a physical platform for maintaining receptors at synapses, and regulate downstream signaling pathways to adjust the molecular composition of the postsynaptic devices necessary to sustain synaptic plasticity.
Gephyrin is the most extensively studied scaffold responsible for organizing the inhibitory postsynaptic density, which is essential for clustering of glycine and $\gamma$-aminobutyric acid type A $\left(\mathrm{GABA}_{\mathrm{A}}\right)$ receptors, inhibitory synaptic transmission and long-term potentiation (reviewed in refs 4-6). Since the discovery of gephyrin in 1982 by Heinrich Betz's group, ${ }^{7}$ its biochemical and cellular properties have been extensively studied. The protein has been shown to bind to various classes of inhibitory synaptic molecules, thereby governing the dynamic processes of inhibitory synapse formation, function and plasticity. Although significant progress has been made in elucidating the role of gephyrin at inhibitory synapses, many unanswered questions remain. In the current review, we describe the domain structure, expression profile and trafficking of gephyrin, and link this information to its synaptic role. We then describe various interacting partners of gephyrin and their roles in inhibitory synapse development. Finally, we discuss the possible implications of gephyrin dysfunctions in some neurological disorders. Owing to space constraints, we focus on recent advances on gephyrin and its interacting proteins, and we also cite classic papers where needed. Other excellent reviews provide detailed discussions regarding the historical context of gephyrin. ${ }^{8,9}$

\section{DOMAIN STRUCTURE}

Gephyrin was originally purified as a $93-\mathrm{kDa}$ protein that associated with glycine receptors (GlyRs) and copurified with polymerized tubulin. ${ }^{10}$ Thus, it was thought to be an anchoring protein of GlyRs. In vertebrates, gephyrin is composed of three

\footnotetext{
${ }^{1}$ Department of Biochemistry, College of Life Science and Biotechnology, Yonsei University, Seoul, Korea and ${ }^{2}$ Department of Psychiatry, Yonsei University College of Medicine, Seoul, Korea

Correspondence: Dr J Ko, Department of Biochemistry, College of Life Science and Biotechnology, Yonsei University, 134 shinchon-dong, Seodaemun-gu, Seoul 120-749, Korea.

E-mail: jaewonko@yonsei.ac.kr
}

Received 9 November 2014; accepted 18 December 2014 


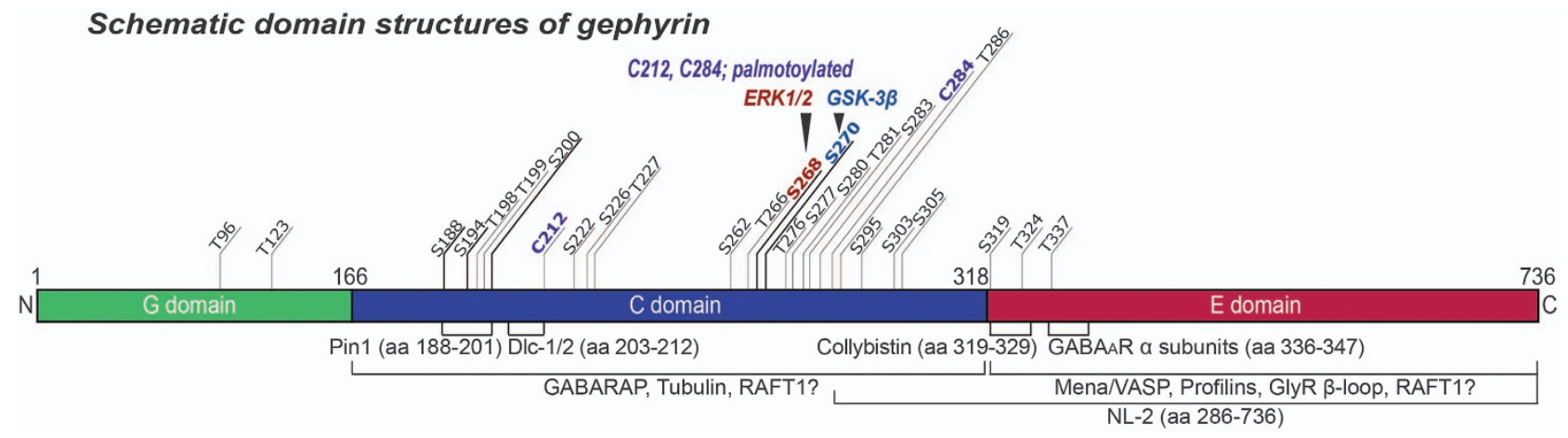

Figure 1 Schematic depiction of gephyrin domains (G, C and E) with sites for posttranslational modifications (phosphorylation and palmitoylation) and binding interactions with other synaptic proteins indicated. Gephyrin is phosphorylated at serine 268 and serine 270 by extracellular signal-regulated kinases 1 and 2 (ERK1/2) and glycogen synthase kinase- $\beta$ (GSK-3 $\beta$ ), respectively. In addition, gephyrin is palmitoylated at cysteine 212 and cysteine 284. N, amino terminus; C, carboxyl terminus; ERK, extracellular signal-regulated kinase; GABARAP, GABA $A_{A}$ receptor-associated protein; GlyR, glycine receptor; GSK, glycogen synthase kinase; NL-2, neuroligin-2; Pin1, peptidylprolyl isomerase NIMA interacting protein 1; RAFT1, rapamycin and FKBP12 target 1; VASP, vasodilator-stimulated phosphoprotein.

major distinct domains: the G, C and E domains (Figure 1). Molecular cloning revealed that gephyrin shows similarity to a group of invertebrate proteins that are essential to synthesize a cofactor required for the activity of molybdenum. ${ }^{11}$ The $\mathrm{G}$ and E domains of gephyrin are homologous to the Escherichia coli enzymes MogA and MoeA, respectively, both of which are involved in molybdenum cofactor biosynthesis, as demonstrated by crystal structure analysis of the trimeric $\mathrm{N}$-terminal domain of gephyrin. ${ }^{12}$ The $\mathrm{C}$ domain of gephyrin contains numerous residues that act as sites for posttranslational modification and binding to other synaptic proteins, such as $\mathrm{GABA}_{\mathrm{A}}$ receptor-associated protein (GABARAP) and dynein light chains 1 and $2 .{ }^{8}$ Thus, the $\mathrm{C}$ domain is believed to be critical for the functions of gephyrin. However, other domains also appear to be required for gephyrin function. For example, individual gephyrin $\mathrm{E}$ domain monomers are bound by the $\beta$-loop of the GlyR $\beta$-subunit, where a serine residue within the binding motif acts as a phosphorylation site that controls the binding affinity to gephyrin. ${ }^{13-15}$ Moreover, vertebrate-specific sequences in the $\mathrm{E}$ domain have been shown to regulate cytosolic aggregation and postsynaptic receptor clustering. The enzymatic and cytosolic aggregations of gephyrin were found to be independent, ${ }^{16}$ and crystal structure analysis of individual gephyrin domains revealed that dimerization of gephyrin $\mathrm{E}$ domains and trimerization of gephyrin $G$ domains triggered the formation of multimeric, hexagonal aggregates. ${ }^{17}$ The multimeric conformations of gephyrin are thought to help position it beneath the plasma membrane, where it forms an anchor for inhibitory receptors. ${ }^{18}$ However, the structure for full-length gephyrin protein has not yet been solved, in part because certain properties of the $\mathrm{C}$ domain complicate the crystallization of the full-length protein.

The gephyrin transcript is subject to extensive alternative splicing ${ }^{10,19,20}$ in all three domains. Each domain contains at least three variable expression cassettes, providing a regulatory mechanism through which the signaling properties of specific synapses may be altered. We do not yet know how the alternative splicing of gephyrin is regulated. However insertion of the $\mathrm{C} 3$ cassette (corresponding to exon 9) was reported to be regulated by Nova proteins, and the presence of Nova in neurons has been correlated with alternative exon skipping in gephyrin. $^{21,22}$ Interestingly, the C3 cassette-containing splice variant of gephyrin predominates in the mouse liver, ${ }^{23}$ indicating that the mechanisms of gephyrin splicing may be tissue-specific. The function of the C4d cassette (corresponding to exon 11) has been studied in the greatest detail. Although it is located in the $\mathrm{N}$-terminal domain of gephyrin, the presence of C4d abolishes GlyR binding. 24 A recent biochemical study demonstrated that different splice variants of gephyrin can form hexameric complexes that differ in their stabilities. ${ }^{25}$ However, additional systematic analyses are needed to explore the significances of other gephyrin splicing variants in various contexts.

\section{EXPRESSION AND LOCALIZATION}

Northern blot analysis identified gephyrin mRNA transcripts in various tissues. ${ }^{10,26}$ Intriguingly, a high diversity of gephyrin transcripts was observed in the skeletal muscle, heart, liver and brain, all of which showed distinct patterns. This observation is in accord with the notion that gephyrin has an important role in both synaptic and metabolic pathways in the nervous system.

In situ hybridization analyses with exon-specific probes revealed that certain gephyrin transcripts are predominantly expressed in specific tissues. ${ }^{26}$ For example, gephyrin transcripts containing the $\mathrm{C} 2$ cassette (corresponding to exon 3) were abundantly expressed at synapses, whereas those containing the $\mathrm{C} 3$ and $\mathrm{C} 4$ cassettes (corresponding to exon 11) were not; ${ }^{27}$ see also Fritschy et al. ${ }^{8}$ for revised gephyrin splicing cassette nomenclature.

Immunohistochemical analyses have shown that gephyrin proteins are primarily localized to GABAergic and glycinergic synapses (but not glutamatergic synapses) in various brain regions. ${ }^{28-33}$ Strikingly, the inhibitory synaptic localization of 
gephyrin was not found to be affected by the depolymerizations of microtubules or actin, suggesting that its targeting mechanism is cytoskeleton-independent. ${ }^{34}$ Recently, quantitative nanoscopy was used to calculate the number of gephyrin molecules and inhibitory synaptic receptor binding sites. ${ }^{35}$ Purely GABAergic synapses were found to harbor $\sim 40-500$ gephyrin molecules and 30-200 $\mathrm{GABA}_{\mathrm{A}}$ receptors organized in microclusters. In contrast, spinal cord synapses, which contain both GlyRs and $\mathrm{GABA}_{\mathrm{A}}$ receptors, showed a twofold higher packing density of gephyrin, suggesting that the binding to GlyRs affected the compactness of the hexagonal gephyrin lattice. ${ }^{35}$ Moreover, although the phosphorylation of gephyrin is known to modulate its binding affinity, clustering and receptor association, it is not yet known whether increased gephyrin cluster stability correlates with tighter packaging within the lattice. ${ }^{35}$ Overall, these data suggest that gephyrin is tightly packed beneath the GlyR-containing postsynaptic membrane.

\section{CLUSTERING}

Immunostaining of cultured neurons with an anti-gephyrin antibody revealed the existence of discrete puncta that could be categorized as large $\left(0.4-10.0 \mu \mathrm{m}^{2}\right)$ or small $\left(<0.2 \mu \mathrm{m}^{2}\right) .{ }^{28}$ The large puncta were restricted to inhibitory synaptic sites, whereas the small puncta were found in extrasynaptic sites, suggesting that high local concentrations of self-assembled gephyrin molecules (i.e., clusters) are required to stabilize synaptic sites. ${ }^{28}$ Neuron-specific molecular mechanisms selectively target and cluster gephyrin molecules at inhibitory postsynaptic sites, while preventing gephyrin from self-aggregating at extrasynaptic sites (indeed, gephyrin forms intracellular microaggregates when overexpressed in non-neuronal cells). ${ }^{36}$ More recently, specific splice variants of collybistin were shown to promote gephyrin clustering in collaboration with $\mathrm{Cdc} 42$ via phosphoinositide-mediated membrane anchoring (refs 37-39; see 'Interacting proteins of gephyrin' subsection for more details).

At inhibitory synapses, molecular diversity arises from heterogeneity in the $\mathrm{GABA}_{\mathrm{A}}$ receptor subunit composition. It can be also derived from the subcellular localization of inhibitory synapses on perisoma, dendrites or axon initial segment, as each of these cellular compartments provides a distinct microenvironment where specific inhibitory synapses are localized. Diverse mechanisms underlying gephyrin clustering may provide additional layer to the complex mode of inhibitory synapse diversity.

\section{POSTTRANSLATIONAL MODIFICATIONS}

Historically, the posttranslational modifications of gephyrin were not thought to be functionally significant, perhaps because the protein was considered to be a structural component of the inhibitory synapse. However, gephyrin has been identified as a phosphoprotein when copurified with the GlyR (which has kinase activity), ${ }^{40}$ and mass spectrometric analyses of rat and mouse brains revealed that gephyrin has 22 phosphorylation sites, most of which are located within the C domain (except for threonine 324, which lies in the $\mathrm{E}$ domain $^{25,41-43}$ ) (Figure 1). These modifications might induce conformational changes by affecting the structure of the $\mathrm{C}$ domain or the neighboring $\mathrm{G}$ and $\mathrm{E}$ domains, thereby altering the clustering, trafficking and binding properties of gephyrin. Interestingly, lithium chloride (an inhibitor of glycogen synthase kinase- $\beta$ (GSK3 $\beta$ )) enhances gephyrin clustering in cultured neurons, and it has been speculated that the mood-stabilizing effect of lithium may be mediated at least partly via this mechanism. ${ }^{44}$

Serine 268 of gephyrin is phosphorylated by extracellular signal-regulated kinases 1 and 2; this synergistically alters gephyrin clustering and alters the amplitude and frequency of miniature inhibitory postsynaptic currents ${ }^{43}$ (Figure 1). In addition, cyclin-dependent kinase 5 mediates the collybistindependent phosphorylation of Ser270, suggesting that multiple signaling pathways converge at this residue of gephyrin. ${ }^{42}$ It is less clear how gephyrin is dephosphorylated by phosphatases. Puzzlingly, one study showed that protein phosphatase 1 directly interacted with gephyrin and that gephyrin clustering was decreased by the application of broad-spectrum phosphatase inhibitors, ${ }^{45}$ whereas two other studies conversely found that the dephosphorylation of gephyrin increased gephyrin clustering. ${ }^{43,44}$ In this context, it seems noteworthy that acute application of tumor necrosis factor- $\alpha$ downregulates inhibitory synaptic transmission via the protein phosphatase 1-dependent trafficking of $\mathrm{GABA}_{\mathrm{A}}$ receptors. ${ }^{46}$

In addition to phosphorylation, gephyrin is subject to palmitoylation ${ }^{47}$ (Figure 1). Gephyrin was initially postulated as a potential substrate for palmitoyl acyltransferase, ${ }^{48}$ and later work confirmed that cysteine 212 and cysteine 284 are palmitoylated by the enzyme, Asp-His-His-Cys (DHHC)-12, which is localized to the Golgi apparatus and dendritic shaft, and directly interacts with gephyrin. ${ }^{47}$ The DHHC-12mediated palmitoylation of gephyrin, which is regulated by $\mathrm{GABA}_{\mathrm{A}}$ receptor activity, is essential for the postsynaptic membrane association and clustering of gephyrin, and has been shown to increase inhibitory synaptic transmission. ${ }^{47}$ It is possible that the palmitoylation of gephyrin may indirectly impact its phosphorylation status, emphasizing the potential complexity of the mechanisms that form the basis for gephyrin clustering.

Gephyrin was found to interact directly with and be subject to proteolysis by the $\mathrm{Ca}^{2+}$-dependent cysteine protease, calpain-1, suggesting that this may be a gephyrin turnover mechanism. ${ }^{44}$ Intriguingly, gephyrin contains two PEST sequences that may be exposed by a conformational change upon its phosphorylation by GSK3 $\beta$, perhaps facilitating the calpain-1-mediated degradation of gephyrin. ${ }^{44}$

\section{INTERACTING PROTEINS OF GEPHYRIN}

Most of the known gephyrin-binding proteins have been primarily identified by yeast two-hybrid screens. Although some of the interactions have been validated in vivo, their significances remain largely unknown (see Table 1 and Figures 1 and 2). 
Table 1 Summary of the synaptic functions of gephyrin-interacting proteins

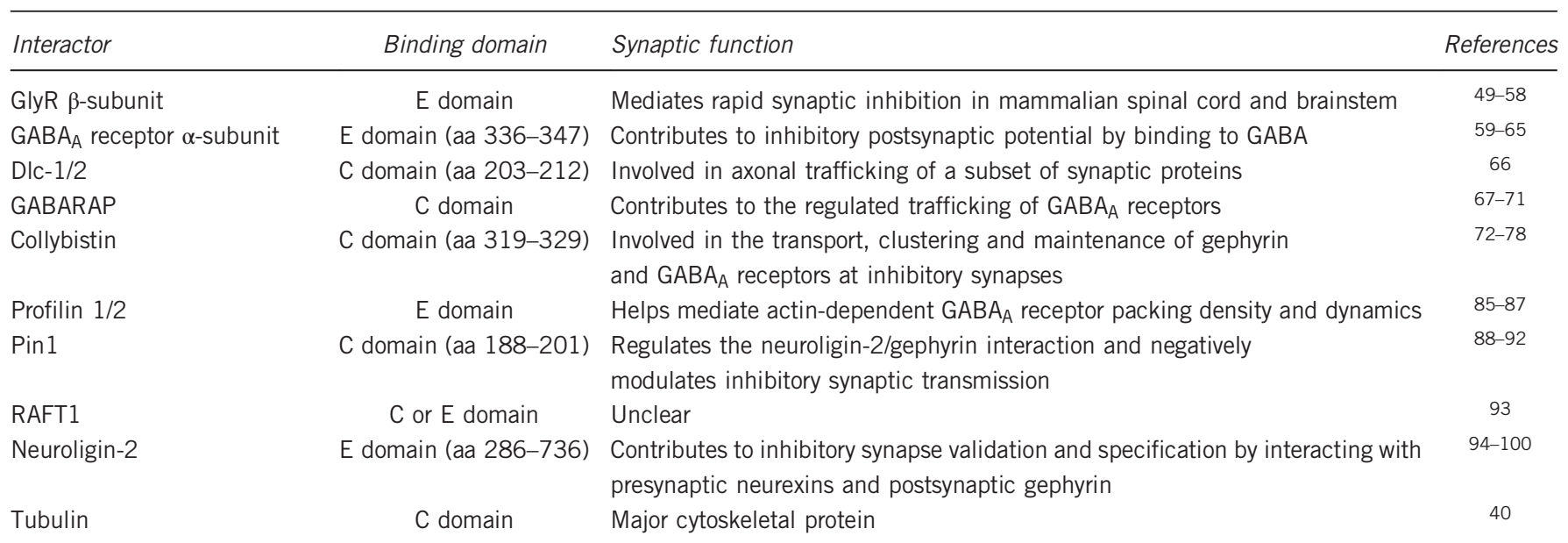

Abbreviations: aa, amino acids; Dlc-1, dynein light chain-1; GABAA, glycine and $\gamma$-aminobutyric acid type A; GABAA receptor-associated protein; GlyR, glycine receptor; Pin1, peptidyl-prolyl isomerase NIMA-interacting protein 1; RAFT1, rapamycin and FKBP12 target 1.

\section{GlyR $\beta$-subunit}

The GlyR is a ligand-gated chloride channel protein that was identified as the first binding protein of gephyrin, as an affinity chromatography study showed that the two could be copurified in stoichiometric amounts. ${ }^{7}$ The cytoplasmic loop of the GlyR $\beta$-subunit was later shown to bind to the $\mathrm{E}$ domain dimerization interface of gephyrin. ${ }^{49,50}$ Coexpression of GlyR with gephyrin was found to change the ligand-binding affinities of human embryonic kidney 293 cells. ${ }^{51}$ Treatment of rat spinal neurons with gephyrin antisense oligonucleotides was shown to block the formation of GlyR clusters in the neuronal membrane, suggesting that gephyrin is required to anchor GlyR in postsynaptic membrane specializations. ${ }^{52}$ Moreover, treatment with a competitive GlyR antagonist (strychnine) or L-type $\mathrm{Ca}^{2+}$ channel blockers inhibited the accumulation of GlyR and gephyrin at postsynaptic membranes in cultured rat spinal neurons, suggesting that the activation of GlyR is necessary for the clustering of gephyrin and GlyR. ${ }^{53,54}$ These notions were later validated in vivo by studies showing that GlyR clustering was disrupted in gephyrin-null mice. ${ }^{55,56}$ GlyR clusters form quickly and reversibly via a two-step process wherein gephyrinindependent cell surface clustering is followed by gephyrinmediated postsynaptic accumulation. ${ }^{24}$ In the latter process, gephyrin breaks the equilibrium between the diffusive and confined states of GlyR to stabilize it at submembranous sites. ${ }^{57}$ Moreover, the oligomerization of gephyrin has been shown to modulate the lateral diffusion of GlyRs. ${ }^{58}$

\section{$\mathrm{GABA}_{\mathrm{A}}$ receptor $\alpha$-subunits}

Although gephyrin was observed to be involved in $\mathrm{GABA}_{\mathrm{A}}$ receptor clustering in vivo, up until recently it was unclear whether this clustering activity was mediated by a direct interaction with gephyrin..$^{59,60}$ For example, a biochemical study failed to demonstrate a direct interaction between $\mathrm{GABA}_{\mathrm{A}} \beta$-subunits ( $\beta 1-\beta 3$ subunits) and gephyrin, ${ }^{49}$ and gephyrin-independent mechanisms were identified as underlying the postsynaptic clustering of certain $\mathrm{GABA}_{\mathrm{A}}$ subtypes. ${ }^{61}$
Therefore, it was surprising when Tretter et al..$^{62}$ reported that a 10-amino-acid hydrophobic motif within the intracellular domain of the $\mathrm{GABA}_{\mathrm{A}} \alpha 2$-subunit was responsible for the inhibitory synaptic accumulation of $\mathrm{GABA}_{\mathrm{A}}$ receptors and underwent direct binding to gephyrin. The authors further showed that $\mathrm{GABA}_{\mathrm{A}}$ receptor subtypes containing the $\alpha 2$-subunit require gephyrin binding for their inhibitory synaptic targeting. ${ }^{2}$ Subsequent studies then identified motifs in the $\mathrm{GABA}_{\mathrm{A}}$ receptor $\alpha 3$ - and $\alpha 1$-subunits that were responsible for binding to the $\mathrm{E}$ domain of gephyrin. ${ }^{60,63}$ Interestingly, some of the gephyrin residues that are key to the binding of $\mathrm{GABA}_{\mathrm{A}}$ receptor subtypes containing the $\alpha 2$ and $\alpha 3$-subunits are also important for binding to GlyRs (albeit with different binding affinities). ${ }^{63}$ The clustering of some $\mathrm{GABA}_{\mathrm{A}}$ receptor subtypes is reportedly dependent on gephyrin, ${ }^{64,65}$ but future work is needed to determine systematically whether other $\mathrm{GABA}_{\mathrm{A}}$ receptor subtypes bind to gephyrin.

\section{Dlc-1 and Dlc-2}

Dynein light chain-1 (Dlc-1; also known as dynein LC8) and its homolog, Dlc-2, were identified as binding proteins of gephyrin in a yeast two-hybrid screen. ${ }^{66}$ Dlc-1 and -2 are subunits of the cytoplasmic dynein motor protein, which mediates the movement of cargo proteins toward the minus ends of microtubule tracks. A central fragment of gephyrin (63 amino acids corresponding to amino acids 181-243) was found to be sufficient to bind Dlc-1/2, and the expression of a Dlc1/2-binding defective gephyrin construct in cultured neurons had no effect on the synaptic localization of gephyrin, suggesting that the inhibitory synaptic targeting of gephyrin does not require the Dlc-binding domain. ${ }^{66}$ This interaction supports the ideas that motor proteins are involved in the intracellular trafficking of gephyrin to the submembranous compartment, and that gephyrin clustering may be regulated in a highly dynamic manner. However, the precise functional significance of this interaction is not yet understood in detail. 


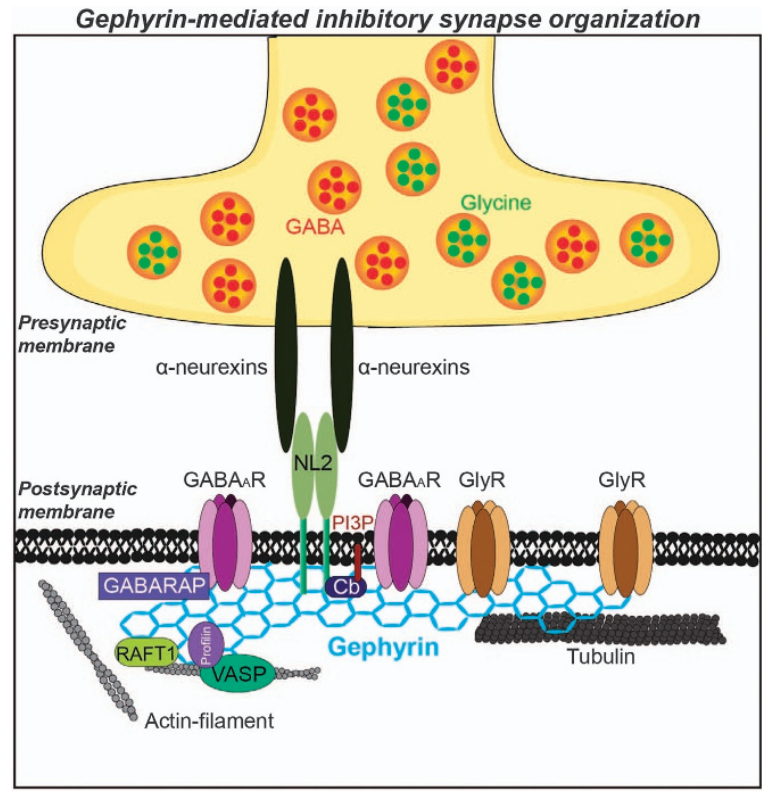

Figure 2 Architecture of gephyrin-containing complexes at inhibitory synapses: the structure of an inhibitory synapse focusing on gephyrin and its interactors at the synaptic membrane and intracellular compartments. Gephyrin (drawn as blue hexagonal lattices beneath the postsynaptic membrane) acts as a hub for inhibitory signal-transduction pathways through $\mathrm{GABA}_{\mathrm{A}}$ receptors, GlyRs and neuroligin-2, and binds to other proteins through its modular structure (see Figure 1 for the domain structure of gephyrin). Specific protein-protein interactions are indicated by overlapping. Protein components of inhibitory synapses with unclear links to gephyrin were omitted. $\mathrm{Cb}$, collybistin; GABARAP, $\mathrm{GABA}_{\mathrm{A}}$ receptor-associated protein; GlyR, glycine receptor; NL-2, neuroligin-2; Pin1, peptidyl-prolyl isomerase NIMAinteracting protein 1; $\mathrm{PI} \mathrm{P}$, phosphatidylinositol 3-phosphate; RAFT1, rapamycin and FKBP12 target 1; VASP, vasodilatorstimulated phosphoprotein.

\section{$\mathrm{GABA}_{\mathrm{A}}$ receptor-associated protein}

GABARAP was originally isolated as a binding partner of the $\mathrm{GABA}_{\mathrm{A}}$ receptor $\gamma 2$-subunit in a yeast two-hybrid screen, and was suggested to have a role in the targeting and clustering of $\mathrm{GABA}_{\mathrm{A}}$ receptors. ${ }^{67} \mathrm{~A}$ later study showed that GABARAP directly interacts with gephyrin. ${ }^{68}$ Strikingly, GABARAP is enriched in intracellular compartments but not gephyrinpositive membrane compartments, indicating that the interaction of GABARAP with gephyrin is not critical for postsynaptic GABAR clustering. ${ }^{68}$ Instead, the interaction of GABARAP with $N$-ethylmaleimide-sensitive factor appears to have a role in the intracellular transport of $\mathrm{GABA}_{\mathrm{A}}$ receptors. ${ }^{69}$ In GABARAP-deficient mice, however, the total number of $\mathrm{GABA}_{\mathrm{A}}$ receptors was unaffected, ${ }^{70}$ indicating that GABARAP is not essential for $\mathrm{GABA}_{\mathrm{A}}$ receptor targeting. The exact cellular roles of GABARAP are currently unknown, but recent sequence analyses have suggested that there are many GABARAP-like proteins constituting a GABARAP-like family across evolution. ${ }^{71}$ Some of these GABARAP-like proteins have been linked to ubiquitination, vesicular transport events, apoptosis and autophagy. GABARAP itself interacts with multiple proteins in addition to the $\mathrm{GABA}_{\mathrm{A}}$ receptor, gephyrin and $N$-ethylmaleimide-sensitive factor, but the functional significances of these interactions are largely unclear at this point. Therefore, further research is needed to elucidate the roles of GABARAP in various contexts at inhibitory synapses.

\section{Collybistin}

Collybistin (also called ARHDH9) was also identified as a gephyrin-interacting protein in a yeast two-hybrid screen. ${ }^{72}$ Based on cDNA cloning and sequence analysis, collybistin was revealed as a neuron-specific dbl-like GDP/GTP exchange factor characterized by three functional domains: an Src homology 3 (SH3) domain; a DBL homology domain for the small GTPase, Cdc42; and a pleckstrin homology domain. ${ }^{72}$ The DBL homology domain of collybistin directly binds to the C-terminal domain of gephyrin. ${ }^{37,73}$ Collybistin is mainly expressed in the brain, ${ }^{37,72,74}$ and alternative splicing generates three isoforms (collybistin I, II and III; differing only in their $\mathrm{C}$ termini and further specifies two different collybistin II variants $\left(\mathrm{CB} 2{ }_{\mathrm{SH} 3}\right.$ and $\mathrm{CB} 2 \mathrm{SH}_{3}$; differing in their $\mathrm{SH} 3$ domain usage). ${ }^{37,73}$ Importantly, the coexpression of collybistin II and gephyrin in non-neuronal cells was shown to induce submembranous collybistin/gephyrin microaggregates that also accumulated hetero-oligomeric GlyRs. ${ }^{72}$ However, $\mathrm{CB}_{2} \mathrm{SH}_{3}$ is inactive in dendritic gephyrin clustering, indicating that the alternative splicing of collybistin has functional importance in the development of inhibitory synapse (Harvey et al.;7 also Tyagarajan et al. and Korber et al. ${ }^{39,75}$ ) for the involvement of $\mathrm{Cdc} 42$ in regulating the clustering of gephyrin). Mutation of glycine 55 to alanine (G55A) in the $\mathrm{SH} 3$ domain of collybistin has been linked to hyperekplexia and epilepsy, reinforcing the importance of this domain of collybistin in its dendritic trafficking and association with gephyrin. However, it should be noted that most of the variants of collybistin found to date in rodents and humans contain an $\mathrm{SH} 3$ domain that inhibits their membrane-targeting ability, ${ }^{37}$ hinting that additional factor(s) are likely to activate collybistin by relieving this $\mathrm{SH} 3$ domain-mediated inhibition. Neuroligin-2 (NL-2) and the Rho-like GTPase, TC10, have been shown to have this role by interacting with the collybistin $\mathrm{SH} 3$ domain. ${ }^{76,77}$ Furthermore, a recent structural study demonstrated that the collybistins can adopt open and closed conformations that act as switchable adaptors, and that NL-2 favors the open conformation by competing with a closed-conformation-favoring intramolecular interaction in collybistin. ${ }^{78}$

The proposed functions of collybistin were demonstrated in vivo: collybistin-deficient mice displayed region-specific reductions in synaptic gephyrin clustering, reduced clustering of the $\mathrm{GABA}_{\mathrm{A}}$ receptor $\gamma 2$-subunit, decreased GABAergic synaptic transmission, impaired hippocampal synaptic plasticity (i.e., increased long-term potentiation and decreased long-term depression) and impaired spatial learning. ${ }^{79}$ Similar functional alterations were reproduced in conditional collybistin-knockout mice. ${ }^{80}$ Moreover, increased granule cell excitability, somatic GABAergic network inhibition and impaired induction of LTP in the dentate gyrus of the 
hippocampus were observed in collybistin-null mice, ${ }^{81}$ suggesting that collybistin deficiency alters GABAergic inhibition, network excitability and synaptic plasticity in certain brain areas. Strikingly, collybistin-deficient mice did not exhibit deficits in glycinergic synaptic transmission, suggesting that collybistin is dispensable for gephyrin-mediated GlyR clustering in glycinergic synapses, but is required for the gephyrinmediated clustering of certain $\mathrm{GABA}_{\mathrm{A}}$ receptors at inhibitory postsynaptic sites. ${ }^{75,82-84}$

\section{Profilin and Mena}

A study seeking the linkage between gephyrin and microfilament identified profilin, Mena and G-actin as gephyrin-binding proteins. ${ }^{85}$ Endogenous profilin and Mena were found to colocalize with gephyrin in the inhibitory synapses of spinal cord neurons, and were enriched in gephyrin-rich domains of the neuronal plasma membrane. ${ }^{85}$ Gephyrin and profilin 1 were shown to form a complex, ${ }^{86}$ but via an unexpected binding mode that required the E domain of gephyrin and the actin/ $\mathrm{PIP}_{2}$-binding site of profilins (Giesemann et al., ${ }^{85}$ but also see Bausen et al. ${ }^{87}$ ). A study examining the potential impact of these multipartite interactions on the function of gephyrin showed that cytochalasin D (an actin-depolymerizing agent) had differential effects on gephyrin clusters that were lost following cytochalasin D treatment of immature cultures but not following the same treatment of more mature cultures. ${ }^{87}$ These data suggest that the formation of a complex between gephyrin and profilin/Mena may contribute to actin cytoskeleton-dependent inhibitory synapse organization. However, further studies are required to fully confirm this hypothesis.

\section{Peptidyl-prolyl isomerase NIMA-interacting protein 1}

Peptidyl-prolyl isomerase NIMA-interacting protein 1 (Pin1) specifically binds phosphorylated serine or threonine residues immediately preceding proline residues, and promotes the cis/ trans isomerization of peptide bonds. ${ }^{88,89}$ These conformational changes profoundly affect on the function of Pin1 substrates by modulating their catalytic activity, phosphorylation status, protein interactions and/or protein stability. ${ }^{90}$ Gephyrin undergoes proline-directed phosphorylation and interacts with Pin1 via a large region that encompasses the $\mathrm{E}$ domain and part of the $\mathrm{C}$ domain, eliciting conformational changes in gephyrin. ${ }^{91}$ The ability of gephyrin to interact with GlyR was significantly decreased in Pin1-deficient mice, reducing the number of GlyR clusters. ${ }^{91}$ Recently, the inhibitory synaptic adhesion molecule, NL-2, was also shown to be a substrate for Pin $1,{ }^{92}$ which negatively regulates the interaction of gephyrin with NL-2 by phosphorylating the serine 714 residue. In addition, the absence of Pin1 was found to promote the formation of NL-2/gephyrin complexes, enrich $\mathrm{GABA}_{\mathrm{A}}$ receptors at inhibitory synaptic sites and inhibit synaptic transmission. ${ }^{92}$ These data suggest a model wherein the Pin1mediated phosphorylation of NL-2 drives conformational changes that detach gephyrin from NL-2.

\section{Rapamycin and FKBP12 target 1}

Rapamycin and FKBP12 target 1 (RAFT1; also called FRAP or mTOR) was found to interact with gephyrin in a yeast twohybrid screen. ${ }^{93}$ The association of gephyrin with RAFT1 was shown to be required for RAFT1-mediated signaling, ${ }^{93}$ and mutations in the minimal gephyrin-binding domains of RAFT1 were found to prevent the activations of $\mathrm{p} 70^{\mathrm{S} 6 \mathrm{~K}}$ and the eukaryotic initiation factor eIF-4E binding-protein, 4E-BP1. ${ }^{93}$ However, the functional significance of this interaction has not yet been clearly defined in the context of gephyrin functions at inhibitory synapses.

\section{Neuroligin-2}

NL-2 is a neuronal transmembrane protein that was identified as the first inhibitory synapse-specific adhesion molecule. ${ }^{94}$ NL-2 interacts with presynaptic neurexins (as do the other neuroligins) and functionally validates inhibitory synapse development in an activity-dependent manner. ${ }^{76,95-98}$ It is not yet clear how NL-2 is specifically targeted to inhibitory synaptic sites, but studies have shown that $\mathrm{GABA}_{\mathrm{A}}$ receptors are dispensable for the inhibitory synaptic targeting of NL-2. ${ }^{99}$ In addition, NL-2, but not other neuroligin paralogs, has been shown to directly interact with gephyrin through a conserved tyrosine residue (Tyr770) that helps recruit gephyrin to NL-2 clusters in cultured neurons. ${ }^{76,100}$ Moreover, NL-2 activates the collybistin-mediated targeting of gephyrin to the plasma membrane in non-neuronal cells. Intriguingly, NL-2 was found to be required for gephyrin to be recruited to the perisomatic site but not to the dendritic shaft. ${ }^{76}$ In addition, deletion of NL-2 was shown to affect both GABAergic and glycinergic synaptic transmission. ${ }^{76}$ Taken together, these data suggest a model for inhibitory postsynaptic assembly whereby the cytoplasmic gephyrin-collybistin complexes are transiently recruited to the plasma membrane sites of NL-2 accumulation via the NL-2/gephyrin interaction, and then other postsynaptic components are further recruited to help construct the functional inhibitory synapse.

\section{SYNAPTIC FUNCTIONS OF GEPHYRIN}

Gephyrin is believed to act as a scaffold at inhibitory synapses, in a manner analogous to that of the prototypic excitatory synaptic scaffold, PSD-95. The best-known function of gephyrin is to bring the inhibitory synaptic receptors and to stabilize them at the inhibitory synapses (Figure 2). Therefore, gephyrin might act as a hub protein, integrating various synaptic activities and signals and adjusting inhibitory synaptic transmission by reorganizing the properties of $\mathrm{GABA}_{\mathrm{A}}$ and GlyRs (Figure 2). However, as discussed above, gephyrin interacts with multiple classes of proteins, implying that it may have broader roles in neurons. Notably, gephyrin interacts with NL-2 and collybistin, suggesting that it may be critical for the maturation or maintenance of inhibitory synapses. As gephyrin undergoes various posttranslational modifications that regulate its clustering at inhibitory synapses, studies aimed at deciphering how and when such posttranslational modifications are regulated will help us understand the synaptic 
functions of this protein. Gephyrin may also act as a sensor that adjusts inhibitory synaptic transmission in response to changes in global network activity, and the alteration of this function appears to activate various signaling cascades. Finally, gephyrin may bind to neuroligin-1 (a paralog of NL-2 that is important for excitatory synaptic function) when it is dephosphorylated at a unique tyrosine residue (Tyr782), and this interaction may be modulated by the binding of neurexin- $1 \beta .^{101}$ Thus, gephyrin is subject to ligand-induced trans-synaptic adhesion signaling, which controls the balance between excitation and inhibition.

It is possible that gephyrin uses alternative pathways to mediate the development of inhibitory synapses. For example, Slitrk3, IgSF9b and Calsyntenin-3 were recently reported to be specifically localized at inhibitory synapses. ${ }^{102-105}$ Future work is warranted to determine whether gephyrin interacts with these adhesion molecules to govern inhibitory synapse formation and function; exploration of this possibility will help address the diverse roles of gephyrin in organizing the development of inhibitory synapses. Super-resolution imaging has revealed the existence of distinct subsynaptic domains, where NL-2 and gephyrin are coupled to constitute one domain, whereas IgSF9 is indirectly linked to NL-2 via another domain. ${ }^{105}$ It would be informative to use similar approaches to examine systematically the localization of other 'endogenous' inhibitory synapse proteins, such as collybistin, Slitrk3 and MDGA1 106

Gephyrin may also be linked to certain forms of synaptic plasticity at inhibitory synapses, such as those that involve rearrangement of the postsynaptic molecular components of GABAergic synapses (e.g., $\mathrm{GABA}_{\mathrm{A}}$ receptors, gephyrin and other structural proteins). ${ }^{6}$ Indeed, CaMKII-dependent phosphorylation of the $\mathrm{GABA}_{\mathrm{A}}$ receptor $\beta 3$-subunit promotes the recruitment of gephyrin from extrasynaptic sites during postsynaptic LTP of inhibition. ${ }^{6}$ Impairment of gephyrin assembly blocks chemically induced postsynaptic LTP of inhibition and the accumulation/confinement of $\mathrm{GABA}_{\mathrm{A}}$ receptors at inhibitory synapses. These results strongly indicate that the immobilization (or clustering) of gephyrin at synapses and the subsequent immobilization of receptors are crucial for postsynaptic LTP of inhibition. The recent development of a new tool, called 'fibronectin intrabodies generated with mRNA display (FingRs)' should allow us to better visualize the dynamic localization of inhibitory synaptic molecules in living neurons, allowing them to be implicated in various forms of inhibitory synaptic plasticity. ${ }^{107}$

\section{DISEASE IMPLICATIONS OF GEPHYRIN}

Some neurological disorders have been linked to gephyrin dysfunctions (e.g., stiff-person syndrome (Moersch-Woltman), hyperekplexia, temporal lobe epilepsy, molybdenum cofactor deficiency, autism and schizophrenia). ${ }^{108-113}$ These diseases may be partly attributed to defects in the glycinergic system, which can be easily understood given the role of gephyrin in GlyR clustering. Gephyrin levels are reduced in the brains of patients suffering from Alzheimer's disease, but its direct involvement in this disorder has not yet been fully explored. ${ }^{114,115}$ Intriguingly, temporal lobe epilepsy has been linked to abnormal operation of the gephyrin splicing machinery. ${ }^{113}$ More specifically, cellular stresses (e.g., alkalosis) increase the proportions of gephyrin splice variants lacking exons encoding the $\mathrm{G}$ domain, potentially altering the activity of gephyrin clustering. ${ }^{116}$ These results suggest that targeting the alternative splicing of gephyrin could provide a possible therapeutic strategy against the above-listed diseases. Modulation of gephyrin clustering could also be a therapeutic target, as restoration of the excitatory-inhibitory balance could ameliorate a subset of neuropsychiatric disorders associated with gephyrin dysfunctions. Chronic treatments with lithium and valproic acid have been widely used to treat epilepsy and bipolar disorder. ${ }^{117}$ Intriguingly, gephyrin clustering is enhanced by lithium treatment, which acts on GSK3 $3 .{ }^{44}$ This emphasizes the potential benefits of targeting gephyrin when seeking to design effective new drugs for mood disorders, including bipolar disorder.

\section{CONCLUSIONS}

It is increasingly clear that gephyrin is crucial for the structure, function and plasticity of inhibitory synapses, and that it may be highly relevant to neural circuits that undergo various forms of inhibition in vivo. However, we still do not fully understand the precise roles of gephyrin at GABAergic and glycinergic synapses. Although a dozen gephyrin-binding proteins (see Figure 2 and Table 1) have been identified to date, most of them have been discovered by yeast two-hybrid screens, which are not exhaustive in isolating physiologically relevant binding partners. In the future, advanced proteomics should be used to identify additional binding proteins and gain additional insights into the synaptic roles of gephyrin. We need a more detailed mechanistic understanding of how inhibitory receptors are dynamically modulated with respect to postsynaptic specializations, and the physiological significance of the posttranslational modification of gephyrin should be broadly examined in conjunction with the known roles of other inhibitory synaptic molecules. Obviously, these future studies will bring us ever closer to understanding the pathological mechanisms underlying various brain disorders caused by dysfunctions of inhibitory synaptic molecules.

\section{CONFLICT OF INTEREST}

The authors declare no conflict of interest.

\section{ACKNOWLEDGEMENTS}

This work was supported by the Yonsei University Future-leading Research Initiative of 2014 (to JK), and in part by Brain Korea 21 (BK21) PLUS program. GC is a fellowship awardee by BK21 PLUS program.

1 Missler M, Sudhof TC, Biederer T. Synaptic cell adhesion. Cold Spring Harb Pespect Biol 2012; 4: a005694.

2 Ko J. The leucine-rich repeat superfamily of synaptic adhesion molecules: LRRTMs and Slitrks. Mol Cells 2012; 34: 335-340. 
3 Um JW, Ko J. LAR-RPTPs: synaptic adhesion molecules that shape synapse development. Trends Cell Biol 2013; 23: 465-475.

4 Tretter V, Mukherjee J, Maric HM, Schindelin H, Sieghart W, Moss SJ. Gephyrin, the enigmatic organizer at GABAergic synapses. Front Cell Neurosci 2012; 6: 23.

5 Tyagarajan SK, Fritschy JM. Gephyrin: a master regulator of neuronal function? Nat Rev Neurosci 2014; 15: 141-156.

6 Petrini EM, Ravasenga T, Hausrat TJ, lurilli G, Olcese U, Racine V et al. Synaptic recruitment of gephyrin regulates surface GABAA receptor dynamics for the expression of inhibitory LTP. Nat Commun 2014; 5: 3921.

7 Pfeiffer F, Graham D, Betz H. Purification by affinity chromatography of the glycine receptor of rat spinal cord. J Biol Chem 1982; 257: 9389-9393.

8 Fritschy JM, Harvey RJ, Schwarz G. Gephyrin: where do we stand, where do we go? Trends Neurosci 2008; 31: 257-264.

9 Tyagarajan SK, Fritschy JM. GABA(A) receptors, gephyrin and homeostatic synaptic plasticity. J Physiol 2010; 588: 101-106.

10 Prior P, Schmitt B, Grenningloh G, Pribilla I, Multhaup G, Beyreuther K et al. Primary structure and alternative splice variants of gephyrin, a putative glycine receptor-tubulin linker protein. Neuron 1992; 8: 1161-1170.

11 Kamdar KP, Shelton ME, Finnerty V. The Drosophila molybdenum cofactor gene cinnamon is homologous to three Escherichia coli cofactor proteins and to the rat protein gephyrin. Genetics 1994; 137 791-801.

12 Sola M, Kneussel M, Heck IS, Betz H, Weissenhorn W. X-ray crystal structure of the trimeric $\mathrm{N}$-terminal domain of gephyrin. J Biol Chem 2001; 276: 25294-25301

13 Bedet C, Bruusgaard JC, Vergo S, Groth-Pedersen L, Eimer S, Triller A et al. Regulation of gephyrin assembly and glycine receptor synaptic stability. J Biol Chem 2006; 281: 30046-30056.

14 Kim EY, Schrader N, Smolinsky B, Bedet C, Vannier C, Schwarz G et al. Deciphering the structural framework of glycine receptor anchoring by gephyrin. EMBO J 2006; 25: 1385-1395.

15 Specht CG, Grunewald N, Pascual O, Rostgaard N, Schwarz G, Triller A. Regulation of glycine receptor diffusion properties and gephyrin interactions by protein kinase C. EMBO J 2011; 30: 3842-3853.

16 Lardi-Studler B, Smolinsky B, Petitjean CM, Koenig F, Sidler C, Meier JC et al. Vertebrate-specific sequences in the gephyrin E-domain regulate cytosolic aggregation and postsynaptic clustering. J Cell Sci 2007; 120: $1371-1382$

17 Kneussel M, Betz $\mathrm{H}$. Clustering of inhibitory neurotransmitter receptors at developing postsynaptic sites: the membrane activation model. Trends Neurosci 2000; 23: 429-435.

18 Sola M, Bavro VN, Timmins J, Franz T, Ricard-Blum S, Schoehn G et al. Structural basis of dynamic glycine receptor clustering by gephyrin. $E M B O$ J 2004; 23: 2510-2519.

19 Smolinsky B, Eichler SA, Buchmeier S, Meier JC, Schwarz G. Splice-specific functions of gephyrin in molybdenum cofactor biosynthesis. J Biol Chem 2008; 283: 17370-17379.

20 Paarmann I, Schmitt B, Meyer B, Karas M, Betz H. Mass spectrometric analysis of glycine receptor-associated gephyrin splice variants. J Biol Chem 2006; 281: 34918-34925.

21 Ule J, Jensen KB, Ruggiu M, Mele A, Ule A, Darnell RB. CLIP identifies Nova-regulated RNA networks in the brain. Science 2003; 302 1212-1215.

22 Licatalosi DD, Mele A, Fak JJ, Ule J, Kayikci M, Chi SW et al. HITS-CLIP yields genome-wide insights into brain alternative RNA processing. Nature 2008; 456: 464-469.

23 Nawrotzki R, Islinger M, Vogel I, Volkl A, Kirsch J. Expression and subcellular distribution of gephyrin in non-neuronal tissues and cells. Histochem Cell Biol 2012; 137: 471-482.

24 Meier J, De Chaldee M, Triller A, Vannier C. Functional heterogeneity of gephyrins. Mol Cell Neurosci 2000; 16: 566-577.

25 Herweg J, Schwarz G. Splice-specific glycine receptor binding, folding, and phosphorylation of the scaffolding protein gephyrin. J Biol Chem 2012; 287: 12645-12656.

26 Ramming M, Kins S, Werner N, Hermann A, Betz H, Kirsch J. Diversity and phylogeny of gephyrin: tissue-specific splice variants, gene structure, and sequence similarities to molybdenum cofactor-synthesizing and cytoskeleton-associated proteins. Proc Natl Acad Sci USA 2000; 97 10266-10271.
27 Kirsch J, Malosio ML, Wolters I, Betz H. Distribution of gephyrin transcripts in the adult and developing rat brain. Eur J Neurosci 1993; 5 1109-1117.

28 Craig AM, Banker G, Chang W, McGrath ME, Serpinskaya AS. Clustering of gephyrin at GABAergic but not glutamatergic synapses in cultured rat hippocampal neurons. J Neurosci 1996; 16: 3166-3177.

29 Giustetto M, Kirsch J, Fritschy JM, Cantino D, Sassoe-Pognetto M. Localization of the clustering protein gephyrin at GABAergic synapses in the main olfactory bulb of the rat. J Comp Neurol 1998; 395: 231-244.

30 Sassoe-Pognetto M, Panzanelli P, Sieghart W, Fritschy JM. Colocalization of multiple GABA(A) receptor subtypes with gephyrin at postsynaptic sites. J Comp Neurol 2000; 420: 481-498.

31 Zucker CL. Localization of gephyrin and glycine receptor subunit immunoreactivity in the rabbit retina. Vis Neurosci 1998; 15: 389-395.

32 Waldvogel HJ, Baer K, Snell RG, During MJ, Faull RL, Rees MI. Distribution of gephyrin in the human brain: an immunohistochemical analysis. Neuroscience 2003; 116: 145-156.

33 Studler B, Sidler C, Fritschy JM. Differential regulation of GABA(A) receptor and gephyrin postsynaptic clustering in immature hippocampal neuronal cultures. J Comp Neurol 2005; 484: 344-355.

34 Allison DW, Chervin AS, Gelfand VI, Craig AM. Postsynaptic scaffolds of excitatory and inhibitory synapses in hippocampal neurons: maintenance of core components independent of actin filaments and microtubules. J Neurosci 2000; 20: 4545-4554.

35 Specht CG, Izeddin I, Rodriguez PC, El Beheiry M, Rostaing P, Darzacq X et al. Quantitative nanoscopy of inhibitory synapses: counting gephyrin molecules and receptor binding sites. Neuron 2013; 79: 308-321.

36 Kirsch J, Kuhse J, Betz H. Targeting of glycine receptor subunits to gephyrin-rich domains in transfected human embryonic kidney cells. Mol Cell Neurosci 1995; 6: 450-461.

37 Harvey K, Duguid IC, Alldred MJ, Beatty SE, Ward H, Keep NH et al. The GDP-GTP exchange factor collybistin: an essential determinant of neuronal gephyrin clustering. J Neurosci 2004; 24: 5816-5826.

38 Reddy-Alla S, Schmitt B, Birkenfeld J, Eulenburg V, Dutertre S, Bohringer $\mathrm{C}$ et al. $\mathrm{PH}$-domain-driven targeting of collybistin but not $\mathrm{Cdc} 42$ activation is required for synaptic gephyrin clustering. Eur J Neurosci 2010; 3: 1173-1184.

39 Tyagarajan SK, Ghosh H, Harvey K, Fritschy JM. Collybistin splice variants differentially interact with gephyrin and $\mathrm{Cdc} 42$ to regulate gephyrin clustering at GABAergic synapses. J Cell Sci 2011; 124: 2786-2796.

40 Langosch D, Hoch W, Betz $\mathrm{H}$. The $93 \mathrm{kDa}$ protein gephyrin and tubulin associated with the inhibitory glycine receptor are phosphorylated by an endogenous protein kinase. FEBS Lett 1992; 298: 113-117.

41 Zacchi P, Antonelli R, Cherubini E. Gephyrin phosphorylation in the functional organization and plasticity of GABAergic synapses. Front Cell Neurosci 2014; 8: 103.

42 Kuhse J, Kalbouneh H, Schlicksupp A, Mukusch S, Nawrotzki R, Kirsch J. Phosphorylation of gephyrin in hippocampal neurons by cyclin-dependent kinase CDK5 at Ser-270 is dependent on collybistin. J Biol Chem 2012; 287: 30952-30966.

43 Tyagarajan SK, Ghosh H, Yevenes GE, Imanishi SY, Zeilhofer HU, Gerrits $\mathrm{B}$ et al. Extracellular signal-regulated kinase and glycogen synthase kinase 3beta regulate gephyrin postsynaptic aggregation and GABAergic synaptic function in a calpain-dependent mechanism. J Biol Chem 2013; 288 9634-9647.

44 Tyagarajan SK, Ghosh H, Yevenes GE, Nikonenko I, Ebeling C, Schwerde $\mathrm{C}$ et al. Regulation of GABAergic synapse formation and plasticity by GSK3beta-dependent phosphorylation of gephyrin. Proc Natl Acad Sci USA 2011; 108: 379-384.

45 Bausen M, Weltzien F, Betz H, O'Sullivan GA. Regulation of postsynaptic gephyrin cluster size by protein phosphatase 1. Mol Cell Neurosci 2010, 44: 201-209.

46 Pribiag $H$, Stellwagen $D$. TNF-alpha downregulates inhibitory neurotransmission through protein phosphatase 1-dependent trafficking of GABA(A) receptors. J Neurosci 2013; 33: 15879-15893.

47 Dejanovic B, Semtner M, Ebert S, Lamkemeyer T, Neuser F, Luscher B et al. Palmitoylation of gephyrin controls receptor clustering and plasticity of GABAergic synapses. PLoS Biol 2014; 12: e1001908.

48 Kang R, Wan J, Arstikaitis P, Takahashi H, Huang K, Bailey AO et al. Neural palmitoyl-proteomics reveals dynamic synaptic palmitoylation. Nature 2008; 456: 904-909.

49 Meyer G, Kirsch J, Betz H, Langosch D. Identification of a gephyrin binding motif on the glycine receptor beta subunit. Neuron 1995; 15 : 563-572. 
50 Schrader N, Kim EY, Winking J, Paulukat J, Schindelin H, Schwarz G. Biochemical characterization of the high affinity binding between the glycine receptor and gephyrin. J Biol Chem 2004; 279: 18733-18741.

51 Takagi T, Pribilla I, Kirsch J, Betz H. Coexpression of the receptor-associated protein gephyrin changes the ligand binding affinities of alpha 2 glycine receptors. FEBS Lett 1992; 303: $178-180$.

52 Kirsch J, Wolters I, Triller A, Betz H. Gephyrin antisense oligonucleotides prevent glycine receptor clustering in spinal neurons. Nature 1993; 366: 745-748.

53 Kirsch J, Betz H. Glycine-receptor activation is required for receptor clustering in spinal neurons. Nature 1998; 392: 717-720.

54 Levi S, Logan SM, Tovar KR, Craig AM. Gephyrin is critical for glycine receptor clustering but not for the formation of functional GABAergic synapses in hippocampal neurons. J Neurosci 2004; 24: 207-217.

55 Feng G, Tintrup H, Kirsch J, Nichol MC, Kuhse J, Betz H et al. Dual requirement for gephyrin in glycine receptor clustering and molybdoenzyme activity. Science 1998; 282: 1321-1324.

56 Fischer $\mathrm{F}$, Kneussel M, Tintrup $\mathrm{H}$, Haverkamp S, Rauen T, Betz $\mathrm{H}$ et al. Reduced synaptic clustering of GABA and glycine receptors in the retina of the gephyrin null mutant mouse. J Comp Neurol 2000; 427: 634-648.

57 Meier J, Vannier C, Serge A, Triller A, Choquet D. Fast and reversible trapping of surface glycine receptors by gephyrin. Nat Neurosci 2001; 4: 253-260

58 Calamai M, Specht CG, Heller J, Alcor D, Machado P, Vannier C et al. Gephyrin oligomerization controls GlyR mobility and synaptic clustering. J Neurosci 2009; 29: 7639-7648.

59 Kneussel M, Hermann A, Kirsch J, Betz H. Hydrophobic interactions mediate binding of the glycine receptor beta-subunit to gephyrin. J Neurochem 1999; 72: 1323-1326.

60 Mukherjee J, Kretschmannova K, Gouzer G, Maric HM, Ramsden S, Tretter $\mathrm{V}$ et $\mathrm{al}$. The residence time of GABA(A)Rs at inhibitory synapses is determined by direct binding of the receptor alphal subunit to gephyrin. J Neurosci 2011; 31: 14677-14687.

61 Kneussel M, Brandstatter JH, Gasnier B, Feng G, Sanes JR, Betz H. Gephyrin-independent clustering of postsynaptic $\mathrm{GABA}(\mathrm{A})$ receptor subtypes. Mol Cell Neurosci 2001; 17: 973-982.

62 Tretter V, Jacob TC, Mukherjee J, Fritschy JM, Pangalos MN, Moss SJ. The clustering of $\mathrm{GABA}(\mathrm{A})$ receptor subtypes at inhibitory synapses is facilitated via the direct binding of receptor alpha 2 subunits to gephyrin. J Neurosci 2008; 28: 1356-1365.

63 Tretter V, Kerschner B, Milenkovic I, Ramsden SL, Ramerstorfer J, Saiepour $L$ et al. Molecular basis of the gamma-aminobutyric acid A receptor alpha3 subunit interaction with the clustering protein gephyrin. J Biol Chem 2011; 286: 37702-37711.

64 Luscher B, Keller CA. Regulation of GABAA receptor trafficking, channel activity, and functional plasticity of inhibitory synapses. Pharmacol Ther 2004; 102: 195-221.

65 Alldred MJ, Mulder-Rosi J, Lingenfelter SE, Chen G, Luscher B. Distinct gamma2 subunit domains mediate clustering and synaptic function of postsynaptic GABAA receptors and gephyrin. J Neurosci 2005; 25: 594-603.

66 Fuhrmann JC, Kins S, Rostaing P, El Far O, Kirsch J, Sheng M et al. Gephyrin interacts with dynein light chains 1 and 2, components of motor protein complexes. J Neurosci 2002; 22: 5393-5402.

67 Wang H, Bedford FK, Brandon NJ, Moss SJ, Olsen RW. GABA(A)-receptorassociated protein links $\mathrm{GABA}(\mathrm{A})$ receptors and the cytoskeleton. Nature 1999; 397: 69-72.

68 Kneussel M, Haverkamp S, Fuhrmann JC, Wang H, Wassle H, Olsen RW et al. The gamma-aminobutyric acid type A receptor (GABAAR)-associated protein GABARAP interacts with gephyrin but is not involved in receptor anchoring at the synapse. Proc Natl Acad Sci USA 2000; 97: 8594-8599.

69 Kittler JT, Rostaing P, Schiavo G, Fritschy JM, Olsen R, Triller A et al. The subcellular distribution of GABARAP and its ability to interact with NSF suggest a role for this protein in the intracellular transport of $\mathrm{GABA}(\mathrm{A})$ receptors. Mol Cell Neurosci 2001; 18: 13-25.

70 O'Sullivan GA, Kneussel M, Elazar Z, Betz H. GABARAP is not essential for GABA receptor targeting to the synapse. Eur J Neurosci 2005; 22: 2644-2648.

71 Mohrluder J, Schwarten M, Willbold D. Structure and potential function of gamma-aminobutyrate type A receptor-associated protein. FEBS J 2009; 276: 4989-5005.
72 Kins S, Betz H, Kirsch J. Collybistin, a newly identified brain-specific GEF, induces submembrane clustering of gephyrin. Nat Neurosci 2000; 3: 22-29.

73 Grosskreutz $Y$, Hermann A, Kins S, Fuhrmann JC, Betz H, Kneussel M. Identification of a gephyrin-binding motif in the GDP/GTP exchange factor collybistin. Biol Chem 2001; 382: 1455-1462.

74 Kneussel $M$, Engelkamp D, Betz $H$. Distribution of transcripts for the brain-specific GDP/GTP exchange factor collybistin in the developing mouse brain. Eur J Neurosci 2001; 13: 487-492.

75 Korber C, Richter A, Kaiser M, Schlicksupp A, Mukusch S, Kuner T et al. Effects of distinct collybistin isoforms on the formation of GABAergic synapses in hippocampal neurons. Mol Cell Neurosci 2012; 50: 250-259.

76 Poulopoulos A, Aramuni G, Meyer G, Soykan T, Hoon M, Papadopoulos T et al. Neuroligin 2 drives postsynaptic assembly at perisomatic inhibitory synapses through gephyrin and collybistin. Neuron 2009; 63 : 628-642.

77 Mayer S, Kumar R, Jaiswal M, Soykan T, Ahmadian MR, Brose N et al. Collybistin activation by GTP-TC10 enhances postsynaptic gephyrin clustering and hippocampal GABAergic neurotransmission. Proc Natl Acad Sci USA 2013; 110: 20795-20800.

78 Soykan T, Schneeberger D, Tria G, Buechner C, Bader N, Svergun D et al. A conformational switch in collybistin determines the differentiation of inhibitory postsynapses. EMBO J 2014; 33: 2113-2133.

79 Papadopoulos T, Korte M, Eulenburg V, Kubota H, Retiounskaia M, Harvey RJ et al. Impaired GABAergic transmission and altered hippocampal synaptic plasticity in collybistin-deficient mice. EMBO J 2007; 26: 3888-3899.

80 Papadopoulos T, Eulenburg V, Reddy-Alla S, Mansuy IM, Li Y, Betz H. Collybistin is required for both the formation and maintenance of GABAergic postsynapses in the hippocampus. Mol Cell Neurosci 2008; 39: 161-169.

81 Jedlicka P, Papadopoulos T, Deller T, Betz H, Schwarzacher SW. Increased network excitability and impaired induction of long-term potentiation in the dentate gyrus of collybistin-deficient mice in vivo. Mol Cell Neurosci 2009; 41: 94-100.

82 Saiepour L, Fuchs C, Patrizi A, Sassoe-Pognetto M, Harvey RJ, Harvey K. Complex role of collybistin and gephyrin in GABAA receptor clustering. J Biol Chem 2010; 285: 29623-29631.

83 Chiou TT, Bonhomme B, Jin H, Miralles CP, Xiao H, Fu Z et al. Differential regulation of the postsynaptic clustering of gamma-aminobutyric acid type A (GABAA) receptors by collybistin isoforms. J Biol Chem 2011; 286: 22456-22468

84 Papadopoulos T, Soykan T. The role of collybistin in gephyrin clustering at inhibitory synapses: facts and open questions. Front Cell Neurosci 2011; 5: 11 .

85 Giesemann T, Schwarz G, Nawrotzki R, Berhorster K, Rothkegel M, Schluter $\mathrm{K}$ et al. Complex formation between the postsynaptic scaffolding protein gephyrin, profilin, and Mena: a possible link to the microfilament system. J Neurosci 2003; 23: 8330-8339.

86 Mammoto A, Sasaki T, Asakura T, Hotta I, Imamura H, Takahashi K et al. Interactions of drebrin and gephyrin with profilin. Biochem Biophys Res Commun 1998; 243: 86-89.

87 Bausen M, Fuhrmann JC, Betz H, O'Sullivan GA. The state of the actin cytoskeleton determines its association with gephyrin: role of ena/VASP family members. Mol Cell Neurosci 2006; 31: 376-386.

88 Lu KP, Hanes SD, Hunter T. A human peptidyl-prolyl isomerase essential for regulation of mitosis. Nature 1996; 380: 544-547.

89 Shen M, Stukenberg PT, Kirschner MW, Lu KP. The essential mitotic peptidyl-prolyl isomerase Pin 1 binds and regulates mitosis-specific phosphoproteins. Genes Dev 1998; 12: 706-720.

90 Wulf G, Finn G, Suizu F, Lu KP. Phosphorylation-specific prolyl isomerization: is there an underlying theme? Nat Cell Biol 2005; 7: 435-441.

91 Zita MM, Marchionni I, Bottos E, Righi M, Del Sal G, Cherubini E et al. Post-phosphorylation prolyl isomerisation of gephyrin represents a mechanism to modulate glycine receptors function. EMBO J 2007; 26: 1761-1771.

92 Antonelli R, Pizzarelli R, Pedroni A, Fritschy JM, Del Sal G, Cherubini E et al. Pin1-dependent signalling negatively affects GABAergic transmission by modulating neuroligin2/gephyrin interaction. Nat Commun 2014; 5: 5066 .

93 Sabatini DM, Barrow RK, Blackshaw S, Burnett PE, Lai MM, Field ME et al. Interaction of RAFT1 with gephyrin required for rapamycin-sensitive signaling. Science 1999; 284: 1161-1164. 
94 Varoqueaux F, Jamain S, Brose N. Neuroligin 2 is exclusively localized to inhibitory synapses. Eur J Cell Biol 2004; 83: 449-456.

95 Chih B, Engelman H, Scheiffele P. Control of excitatory and inhibitory synapse formation by neuroligins. Science 2005; 307: 1324-1328.

96 Graf ER, Zhang X, Jin SX, Linhoff MW, Craig AM. Neurexins induce differentiation of GABA and glutamate postsynaptic specializations via neuroligins. Cell 2004; 119: 1013-1026.

97 Chubykin AA, Atasoy D, Etherton MR, Brose N, Kavalali ET, Gibson JR et al. Activity-dependent validation of excitatory versus inhibitory synapses by neuroligin-1 versus neuroligin-2. Neuron 2007; 54: 919-931.

98 Sudhof TC. Neuroligins and neurexins link synaptic function to cognitive disease. Nature 2008; 455: 903-911.

99 Patrizi A, Scelfo B, Viltono L, Briatore F, Fukaya M, Watanabe $M$ et al. Synapse formation and clustering of neuroligin-2 in the absence of GABAA receptors. Proc Natl Acad Sci USA 2008; 105: 13151-13156.

100 Kang Y, Ge Y, Cassidy RM, Lam V, Luo L, Moon KM et al. A combined transgenic proteomic analysis and regulated trafficking of neuroligin-2. J Biol Chem 2014; 289: 29350-29364.

101 Giannone G, Mondin M, Grillo-Bosch D, Tessier B, Saint-Michel E, Czondor $\mathrm{K}$ et al. Neurexin-1beta binding to neuroligin-1 triggers the preferential recruitment of PSD-95 versus gephyrin through tyrosine phosphorylation of neuroligin-1. Cell Rep 2013; 3: 1996-2007.

102 Yim YS, Kwon Y, Nam J, Yoon HI, Lee K, Kim DG et al. Slitrks control excitatory and inhibitory synapse formation with LAR receptor protein tyrosine phosphatases. Proc Natl Acad Sci USA 2013; 110: 4057-4062.

103 Takahashi H, Katayama K, Sohya K, Miyamoto H, Prasad T, Matsumoto Y et al. Selective control of inhibitory synapse development by Slitrk3PTPdelta trans-synaptic interaction. Nat Neurosci 2012; 15: 389-398.

104 Um JW, Pramanik G, Ko JS, Song MY, Lee D, Kim H et al. Calsyntenins function as synaptogenic adhesion molecules in concert with neurexins. Cell Rep 2014; 6: 1096-1109.

105 Woo J, Kwon SK, Nam J, Choi S, Takahashi H, Krueger D et al. The adhesion protein IgSF9b is coupled to neuroligin 2 via S-SCAM to promote inhibitory synapse development. J Cell Biol 2013; 201: 929-944.

106 Lee K, Kim Y, Lee SJ, Qiang Y, Lee D, Lee HW et al. MDGAs interact selectively with neuroligin-2 but not other neuroligins to regulate inhibitory synapse development. Proc Natl Acad Sci USA 2013; 110 336-341.

107 Gross GG, Junge JA, Mora RJ, Kwon HB, Olson CA, Takahashi TT et al. Recombinant probes for visualizing endogenous synaptic proteins in living neurons. Neuron 2013; 78: 971-985.

108 Butler MH, Hayashi A, Ohkoshi N, Villmann C, Becker CM, Feng G et al. Autoimmunity to gephyrin in Stiff-Man syndrome. Neuron 2000; 26 307-312.
109 Reiss J, Johnson JL. Mutations in the molybdenum cofactor biosynthetic genes MOCS1, MOCS2, and GEPH. Hum Mutat 2003; 21 569-576.

110 Reiss J, Lenz U, Aquaviva-Bourdain C, Joriot-Chekaf S, Mention-Mulliez K, Holder-Espinasse M. A GPHN point mutation leading to molybdenum cofactor deficiency. Clin Genet 2011; 80: 598-599.

111 Rees MI, Harvey K, Ward H, White JH, Evans L, Duguid IC et al. Isoform heterogeneity of the human gephyrin gene (GPHN), binding domains to the glycine receptor, and mutation analysis in hyperekplexia. J Biol Chem 2003; 278: 24688-24696.

112 Fang M, Shen L, Yin H, Pan YM, Wang L, Chen D et al. Downregulation of gephyrin in temporal lobe epilepsy neurons in humans and a rat model. Synapse 2011; 65: 1006-1014.

113 Lionel AC, Vaags AK, Sato D, Gazzellone MJ, Mitchell EB, Chen HY et al. Rare exonic deletions implicate the synaptic organizer Gephyrin (GPHN) in risk for autism, schizophrenia and seizures. Hum Mol Genet 2013; 22 2055-2066.

114 Agarwal S, Tannenberg RK, Dodd PR. Reduced expression of the inhibitory synapse scaffolding protein gephyrin in Alzheimer's disease. $J$ Alzheimers Dis 2008; 14: 313-321.

115 Hales CM, Rees H, Seyfried NT, Dammer EB, Duong DM, Gearing M et al. Abnormal gephyrin immunoreactivity associated with Alzheimer disease pathologic changes. J Neuropathol Exp Neurol 2013; 72: 1009-1015.

116 Forstera B, Belaidi AA, Juttner R, Bernert C, Tsokos M, Lehmann TN et al. Irregular RNA splicing curtails postsynaptic gephyrin in the cornu ammonis of patients with epilepsy. Brain 2010; 133 3778-3794.

117 Wang CC, Chen PS, Hsu CW, Wu SJ, Lin CT, Gean PW. Valproic acid mediates the synaptic excitatory/inhibitory balance through astrocytes-a preliminary study. Prog Neuropsychopharmacol Biol Psychiatry 2012; 37: 111-120.

(ㄷ) (1) () $\odot$ This work is licensed under a Creative Commons Attribution-NonCommercial-NoDerivs 3.0 Unported License. The images or other third party material in this article are included in the article's Creative Commons license, unless indicated otherwise in the credit line; if the material is not included under the Creative Commons license, users will need to obtain permission from the license holder to reproduce the material. To view a copy of this license, visit http://creativecommons.org/licenses/by-nc-nd/3.0/ 